\title{
Relationships between structure of the tree component and environmental variables in a subtropical seasonal forest in the upper Uruguay River valley, Brazil ${ }^{1}$
}

Máida Ariane de Mélo², Jean Carlos Budke ${ }^{3,5}$ and Carlos Henke-Oliveira ${ }^{4}$

Received: 18 December, 2011. Accepted: 25 July, 2013

\begin{abstract}
This study aimed to analyze relationships among the structure of the tree component, edaphic variables and canopy discontinuity along a toposequence in a seasonal upland (hillside) forest in southern Brazil. Soil and vegetation were sampled in 25 plots of $20 \times 20 \mathrm{~m}$ each. We described the vegetation in terms of structure, richness and diversity, as well as by species distribution patterns. We evaluated canopy continuity, determined sloping and calculated spatial coordinates. We applied partial canonical correspondence analysis (pCCA) to determine whether species distribution correlated with environmental and spatial variables. We identified 1201 individuals belonging to 76 species within 30 families. The species with highest density and frequency were Gymnanthes concolor Spreng., Calyptranthes tricona D.Legrand, Eugenia moraviana O.Berg and Trichilia claussenii DC. The pCCAs indicated significant correlations with environmental and spatial variables. Sand content, boron content and soil density collectively explained $36.17 \%$ of the species matrix variation (total inertia), whereas the spatial variables $x, y$ and $x y^{2}$ collectively explained $14.27 \%$. The interaction between environmental and spatial variables explained nearly 4.5\%. However, $45.05 \%$ remained unexplained, attributed to stochastic variation or unmeasured variables. Terrain morphology and canopy discontinuity had no apparent influence on richness, and changes in species distribution were correlated with sloping, which affects soil features and determines the directional distribution of some species.
\end{abstract}

Key words: sloping, soil drainage, spatial autocorrelation, toposequence

\section{Introduction}

Many studies in ecology aim to understand the rules of ecological assemblages of natural communities at different scales. For plant communities, the description of these patterns emphasizes the importance of spatial and temporal context in ecological processes that regulate coexistence or exclusion among species. Studies of the factors that promote environmental variation perceptible at the community level (local scale), such as physical and chemical variations in soil nutrient availability, humidity, light intensity, topography and intraspecific and interspecific competition (Huston 1994) may help to elucidate processes that generate or maintain the structure and diversity of a forest, allowing a better understanding of how certain patterns of spatial organization are able to influence the functioning of the community (Bell et al. 1993).
The landscape influences various environmental characteristics, such as light intensity, the distribution of nutrients and the water saturation of the soil (van den Berg \& Santos 2003), and may act indirectly on the distribution of species (Budke et al. 2010), especially in areas with steep inclines. In this regard, several studies have demonstrated the importance of the topography and patterns that occur in areas with a sloping landscape-the flow of nutrients and water from the top to the base and its influence on the chemical and physical properties of the soil (Neary et al. 2009), as well as the interaction between vegetation and light incidence-which can lead to differences in the composition of tree communities and the distribution of many tree species (Clark et al. 1996).

Studies conducted in southern Brazil have shown the relationship between the distribution of tree species and

\footnotetext{
${ }^{1}$ Based on the Master's dissertation of the first Author

${ }^{2}$ Universidade Regional Integrada do Alto Uruguai e das Missões, Programa de Pós-Graduação em Ecologia, Erechim, RS, Brazil

${ }^{3}$ Universidade Regional Integrada do Alto Uruguai e das Missões, Departamento de Ciências Biológicas, Laboratório de Sistemática e Ecologia Vegetal

- ECOSSIS, Erechim, RS, Brazil

${ }^{4}$ Universidade de Brasília, Departamento de Ecologia, Brasília, DF, Brazil

${ }^{5}$ Author for correspondence: jean@uricer.edu.br
} 
factors associated with topography, such as riparian forests along flood gradients (Budke et al. 2010; Giehl \& Jarenkow 2008) and hillside forests (Sühs \& Budke 2011, Loregian et al. 2012). In general, studies have shown that most species have clustered spatial distribution, and that many generate dense clusters, decreasing the richness and abundance of other species in nearby areas. Sühs \& Budke (2011) evaluated the distribution and association among tree species in a hillside forest, having observed greater association among species at more advanced successional stages and greater dissociation among species at distinct stages (for example, pioneer and shade-tolerant). These results highlight the role of biotic relationships, whereas relationships of facilitation and competition may often result in spatial patterns that are less dependent upon physical environment.

Although these factors are extremely important on the community scale, on a regional scale, climatic factors have been identified as determinants of the distribution of plant species (Giehl \& Jarenkow 2012). From this perspective, deciduous forests have been described as being strongly associated with the seasonality of precipitation and temperature (Oliveira-Filho et al. 2009), which directly affect leaf fall throughout the year. The debate over the expansion of forested areas during the late Holocene in southern Brazil (Behling \& Pillar 2007) has greatly encouraged a discussion on the floristic elements that compose these forests, especially due to the influx of species from different climates-especially humid tropical, Antarctic and tropical dry (deciduous) (Jarenkow \& Budke 2009).

This study aims to investigate the relationship between the distribution of tree species and spatial-environmental variables in a hillside forest situated on a moderate slope gradient (average slope of 25\%) and that, therefore, could offer different establishment conditions for tree species, suggesting a structural change along the gradient. Thus, the guiding hypothesis on the forest structure is that there is variation in the abundance of tree species throughout the toposequence, initially subject to soil variations and to the structure of the canopy itself. Based on these premises, we sought to answer the following questions: "What is the structure of the tree component of a seasonal hillside forest in the Uruguay River valley of southern Brazil?"; and "What are the main factors affecting the distribution of local abundance of such species?"

\section{Material and methods}

\section{Study site}

The study area (central coordinates at $27^{\circ} 28^{\prime} 9^{\prime \prime} \mathrm{S}$; $51^{\circ} 54^{\prime} 5^{\prime \prime} \mathrm{W}$ ) is located in the municipality of Marcelino Ramos, in the northern micro-region of the Brazilian state of Rio Grande do Sul, with elevations ranging from $372 \mathrm{~m}$ to $594 \mathrm{~m}$ and an average slope of $28.7 \%$ (Fetter \& Henke-Oliveira, 2010). The area comprises 469.7 hectares, with an original predominance of seasonal semideciduous subtropical broadleaf submontane forest (Oliveira-Filho 2009). In some difficult to access areas, especially slopes with steep inclines, some of the remaining vegetation has reached an advanced stage of ecological succession, suggesting the absence of selective cutting (timber extraction). The present study was carried out on one such slope with northern exposure.

According to the Köppen classification system, the climate of the region is type Cfa. The average monthly temperature ranges from approximately $12.5^{\circ} \mathrm{C}$ in the coldest month to approximately $22.0^{\circ} \mathrm{C}$ in the hottest month. Frost occurs frequently between May and August, especially at the higher elevations. There is no consistently dry period in the year, and the average annual rainfall is $1750 \mathrm{~mm}$ (Bernardi \& Budke 2010). The predominant soil types in the study area are red latosols (typic hapludox), together with dystrophic entisols and dystrophic udorthents in the most elevated parts. The particle size analysis of the soil (at 0-20 $\mathrm{cm}$ in depth), performed at the Soil Analysis Laboratory of the Universidade Federal do Rio Grande do Sul (UFRGS, Federal University Rio Grande do Sul) School of Agronomy, revealed that it is clayey, especially at the lower elevations, and that the soil can hold a large volume of water and minerals, but has a deficient capacity for aeration and drainage.

For the collection of samples, 25 plots were established, $20 \mathrm{~m}$ apart (Mueller-Dombois \& Ellenberg 1974), arranged in a toposequence with northern exposure. Each plot measured $20 \times 20 \mathrm{~m}$, the total area therefore being $400 \mathrm{~m}^{2}$. We sampled all trees with a diameter at breast height $(\mathrm{DBH}) \geq$ $15 \mathrm{~cm}$. Individuals exhibiting branching below $1.3 \mathrm{~m}$ (i.e., below breast height) were included in the sample if one or more of the stems reached the minimum DBH. Any individual located on the boundary of a plot was recorded if more than half of its basal area was within the plot. For each individual sampled, we estimated the total height using a collecting rod of known length.

Specimens were identified down to the species level by consulting the specialized literature, by making comparisons with specimens in herbarium collections and by sending queries to specialists when necessary. The sample material was processed according to standard procedures and subsequently incorporated into the collection of the HPBR Herbarium at Universidade Regional Integrada do Alto Uruguai e das Missões - URI. The nomenclature follows Sobral et al. (2006), and species classification follows the Angiosperm Phylogeny Group III guidelines (APG III 2009). Structural parameters were estimated with the program FITOPAC 2 (Shepherd 2006), obtaining absolute values for density, frequency and dominance.

Within each plot, we collected five topsoil samples $(0-20$ $\mathrm{cm}$ ) which were then mixed and homogenized to form a composite sample of approximately $500 \mathrm{~g}$ of soil. Samples for chemical and particle size analysis were sent to the Soil Analysis Laboratory of the UFRGS School of Agronomy. 
Samples for the analysis of organic matter content, moisture and density of the soil were collected with the aid of a pitcher-type auger with a container $20 \mathrm{~cm}$ in height and 2 in. in diameter. We took care to remove the layer of leaf litter before collecting soil. For each plot, soil compaction was measured using a penetrometer with a dynamometer ring (Solotest, São Paulo, Brazil). Five measurements were made, and the arithmetic mean was obtained for each plot. Likewise, classes of rockiness were assigned (Santos et al. 2005), considering the proportion of the soil surface area and mass occupied by pebbles $(2-20 \mathrm{~cm}$ in diameter) and stones $(20-100 \mathrm{~cm}$ in diameter). The sampling was performed by visual analysis, in which $0=$ not rocky to slightly rocky (pebbles or stones occupying $<1 \%$ of the area); $1=$ moderately rocky $(1-3 \%) ; 2=\operatorname{rocky}(3-15 \%) ; 3=$ very rocky $(15-50 \%)$; and $4=$ extremely rocky (over $50 \%$ ). For each plot, the sloping was evaluated according to the categories proposed by Santos et al. (2005), as follows: $0=$ flat terrain (grade of $<3 \%$ ); $1=$ slightly inclined $(3-8 \%)$; 2 = moderately inclined (8-20\%); 3 = strongly inclined $(20-45 \%)$; and $4=$ steep $(45-75 \%)$. The evaluation and quantification of the conformation of the ground surface by means of sloping categories allowed the plots to be arranged in order of increasing slope, starting from the highest part of the toposequence and considering the north-south geographical orientation based on the initial sampling design and the corresponding spatial variable $y$.

The discontinuity of the canopy was evaluated by means of hemispherical images obtained with the aid of a Canon EOS 300 camera equipped with a Raynox DCR 187 CFPRO $185^{\circ}$ circular lens converter, allowing a $180^{\circ}$ image to be obtained. The images were taken during the spring, in the center of each plot and $1.5 \mathrm{~m}$ above ground level. The grayscale images were converted to black and white, the white corresponding to openings in the canopy and to black to areas closed off by the canopy. The edited photos were analyzed using the program Gap Light Analyzer 2.0 by calculating the proportion of canopy openness in $10 \times$ $10 \mathrm{~m}$ sub-units, and generating, a posteriori, an average of discontinuity for each plot (Frazer et al. 1999).

\section{Data analysis}

The soil variables, rockiness levels, sloping levels, average soil compaction levels and average canopy openness levels were the set of environmental variables used in the analyses. The spatial variables consisted of the coordinates of the geometric center of the plot, $x$ and $y$, plus seven variables derived from them $-x^{2}, x^{3}, y^{2}, y^{3}, x y, x^{2} y$ and $x y^{2}$-following the polynomial model proposed by Borcard et al. (1992). For these variables, it is worth noting that $x$ is the variation on the east-west axis, and $y$ in the north-south axis in regard to the arrangement of the plots.

In order to determine whether quantitative variations in tree species correlated with environmental and spatial variables, we adopted partial canonical correspondence analysis (pCCA), performed following the interactive procedure described by Borcard et al. (1992), which requires the preparation of three matrices. The first matrix represents species density and consists of the number of individuals per plot; in the present study, only species with more than five sampled individuals were included. As recommended by ter Braak \& Smilauer (1998), the density values underwent logarithmic transformation prior to the analysis process because the distributions showed very low frequencies for the higher values. The other two are the spatial and environmental matrices described above. The variables evaluated in percentage values were transformed by arc sine function of the square root.

Subsequently, there were four pCCAs related to the species matrix: with environmental variables $\left(\mathrm{pCCA}_{1}\right)$; with spatial variables $\left(\mathrm{pCCA}_{2}\right)$; with environmental variables and spatial covariates $\left(\mathrm{pCCA}_{3}\right)$; and with spatial variables and environmental covariates $\left(\mathrm{pCCA}_{4}\right)$. For this, we used the program CANOCO 4.5 (Braak \& Smilauer 1998). In $\mathrm{pCCA}_{1}$ and $\mathrm{pCCA}_{2}$, we used the progressive selection of environmental variables together with Monte Carlo tests to determine the significance of relationships and to eliminate variables that presented strong correlations with others already included in the model. Monte Carlo tests (Braak \& Smilauer 1998) were applied to all four pCCAs, and the results were used in order to estimate the amount of variation in species abundance that was distinctly explained by environmental and spatial variables ( $\mathrm{pCCA}_{1}$ and $\mathrm{pCCA}_{2}$ ), the proportion indistinctly explained by the two sets of variables $\left(\mathrm{pCCA}_{3}\right.$ and $\mathrm{pCCA}_{4}$ ) and the proportion of variation that was unexplained (Borcard et al. 1992).

\section{Results}

We sampled 1201 individuals across 76 species in 30 families (Tab. 1). Myrtaceae was the family with the greatest richness, with 12 species, followed by Fabaceae, with nine; Lauraceae, with five; Meliaceae, Rutaceae, Salicaceae and Sapindaceae, with four each; and Boraginaceae and Rubiaceae, with three each. Of the 30 families, four accounted for $74 \%$ of the individuals, Myrtaceae occupying the first position (28.4\%), followed by Euphorbiaceae (28.3\%), Meliaceae (10.9\%) and Lauraceae (6.2\%). Each of the other families accounted for $\leq 5 \%$. Gymnanthes concolor, Calyptranthes tricona, Eugenia moraviana and Trichilia claussenii were the species with the highest density and frequency, collectively accounting for $57 \%$ of the individuals sampled (Tab. 1).

The analysis of the distribution of individuals by height (Fig. 1) revealed that the majority (49.7\%) were in the 7-11 $\mathrm{m}$ height class and that the numbers of individuals decreased progressively across the subsequent classes. Among the species whose individuals included medium-sized trees Eugenia Moraviana, Trichilia claussenii and Ocotea odorifera stand out. Emergent trees with a height $\geq 17 \mathrm{~m}$ included individu- 
Table 1. Species and their botanical families, together with the structural parameters absolute density, absolute dominance and absolute frequency, for tree species sampled in a remnant of subtropical seasonal forest in the upper Uruguay River Valley, southern Brazil.

\begin{tabular}{|c|c|c|c|c|}
\hline Species & Family & $\mathrm{AD}$ & ADo & $\mathrm{AF}$ \\
\hline Gymnanthes concolor Spreng. - SWD & Euphorbiaceae & 309 & 1.4729 & 100 \\
\hline Calyptranthes tricona D. Legrand - PUB & Myrtaceae & 205 & 2.8443 & 100 \\
\hline Eugenia moraviana O.Berg - PUB & Myrtaceae & 85 & 2.3561 & 96 \\
\hline Trichilia claussenii C.DC. - SWD & Meliaceae & 84 & 0.7457 & 96 \\
\hline Pilocarpus pennatifolius Lem. - PUB & Rutaceae & 44 & 0.2791 & 40 \\
\hline Ocotea odorifera (Vell.) Rohwer - ATL & Lauraceae & 36 & 1.3228 & 76 \\
\hline Sebastiania brasiliensis Spreng. - SWD & Euphorbiaceae & 31 & 0.5298 & 44 \\
\hline Chrysophyllum marginatum (Hook. \& Arn.) Radlk. - PUB & Sapotaceae & 26 & 0.6576 & 60 \\
\hline Nectandra megapotamica (Spreng.) Mez - SWD & Lauraceae & 22 & 2.1193 & 60 \\
\hline Calyptranthes grandifolia O. Berg - ATL & Myrtaceae & 20 & 0.6548 & 56 \\
\hline Cabralea canjerana (Vell.) Mart - SWD & Meliaceae & 19 & 1.7787 & 40 \\
\hline Trichilia elegans A. Juss. - PUB & Meliaceae & 18 & 0.1059 & 44 \\
\hline Myrsine umbellata Mart. - SWD & Primulaceae & 17 & 0.4069 & 36 \\
\hline Casearia silvestris Sw. - SWD & Salicacaceae & 15 & 0.4486 & 48 \\
\hline Calliandra foliolosa Benth. - PUB & Fabaceae & 15 & 0.0964 & 48 \\
\hline Prunus myrtifolia (L.) Urb. - SWD & Rosaceae & 14 & 1.3883 & 44 \\
\hline Calyptranthes lucida Mart. ex DC. - ATL & Myrtaceae & 13 & 0.4909 & 36 \\
\hline Ilex dumosa Reissek - SWD & Aquifoliaceae & 13 & 0.2540 & 36 \\
\hline Chrysophyllum gonocarpum (Mart. \& Eichler) Engl. - PUB & Sapotaceae & 12 & 0.1442 & 44 \\
\hline Lonchocarpus campestris Mart. ex Benth. - PUB & Fabaceae & 11 & 0.4042 & 36 \\
\hline Cedrela fissilis Vell. - SWD & Meliaceae & 10 & 0.6927 & 32 \\
\hline Allophylus edulis (A. St.-Hil., Cambess. \& A. Juss.) Radlk. - SWD & Sapindaceae & 10 & 0.3019 & 24 \\
\hline Ocotea diospyrifolia (Meisn.) Mez - PUB & Lauraceae & 9 & 0.8320 & 24 \\
\hline Cordia trichotoma (Vell.) Arráb. ex Steud. - SWD & Boraginaceae & 8 & 0.3824 & 28 \\
\hline Inga marginata Willd. - SWD & Fabaceae & 8 & 0.0513 & 32 \\
\hline Cupania vernalis Cambess. - SWD & Sapindaceae & 8 & 0.0800 & 16 \\
\hline Nectandra lanceolata Nees - SWD & Lauraceae & 7 & 0.8166 & 20 \\
\hline Eugenia schuechiana O.Berg - PUB & Myrtaceae & 7 & 0.0463 & 28 \\
\hline Luehea divaricata Mart. \& Zucc. - SWD & Malvaceae & 6 & 0.5480 & 20 \\
\hline Casearia decandra Jacq. - PUB & Salicaceae & 6 & 0.1087 & 20 \\
\hline Syagrus romanzoffiana (Cham.) Glassman - SWD & Arecaceae & 6 & 0.2164 & 12 \\
\hline Sloanea monosperma Vell. - PUB & Elaeocarpaceae & 5 & 1.6220 & 20 \\
\hline Parapiptadenia rigida (Benth.) Brenan - PUB & Fabaceae & 5 & 0.9110 & 20 \\
\hline Cordia americana (L.) Gottschling \& J.E.Mill. - PUB & Boraginaceae & 5 & 0.4411 & 16 \\
\hline Zanthoxylum caribaeum Lam. - ATL & Rutaceae & 5 & 0.1945 & 20 \\
\hline Coussarea contracta (Walp.) Müll.Arg. - PUB & Rubiaceae & 5 & 0.0491 & 20 \\
\hline Apuleia leiocarpa (Vogel) J.F. Macbr. - PUB & Fabaceae & 5 & 0.0535 & 16 \\
\hline Campomanesia xanthocarpa O.Berg - SWD & Myrtaceae & 4 & 0.5802 & 16 \\
\hline Balfourodendron riedelianum (Engl.) Engl. - PUB & Rutaceae & 4 & 0.1247 & 16 \\
\hline Aspidosperma australe Müll.Arg. - PUB & Apocynaceae & 4 & 0.1080 & 16 \\
\hline Ficus luschnathiana (Miq.) Miq. - SWD & Moraceae & 4 & 0.0722 & 12 \\
\hline Cordia ecalyculata Vell. - PBU & Boraginaceae & 4 & 0.0549 & 12 \\
\hline Celtis iguanaea (Jacq.) Sarg. - SWD & Cannabaceae & 4 & 0.0315 & 12 \\
\hline Coutarea hexandra (Jacq.) K. Schum - PUB & Rubiaceae & 4 & 0.0771 & 8 \\
\hline Styrax leprosus Hook. \& Arn. - PUB & Styracaceae & 3 & 0.2532 & 12 \\
\hline Allophylus puberulus (Cambess.) Radlk. - PUB & Sapindaceae & 3 & 0.0829 & 12 \\
\hline
\end{tabular}


Table 1. Continuation.

\begin{tabular}{|c|c|c|c|c|}
\hline Species & Family & $\mathrm{AD}$ & ADo & $\mathrm{AF}$ \\
\hline Annona neosalicifolia H.Rainer - SWD & Annonaceae & 3 & 0.0637 & 12 \\
\hline Banara tomentosa Clos - PUB & Salicaceae & 3 & 0.0469 & 12 \\
\hline Jacaranda micrantha Cham. - PUB & Bignoniaceae & 2 & 0.0705 & 8 \\
\hline Lonchocarpus nitidus (Vogel) Benth. - PUB & Fabaceae & 2 & 0.0611 & 8 \\
\hline Pisonia ambigua Heimerl . - PUB & Nyctaginaceae & 2 & 0.0526 & 8 \\
\hline Urera baccifera (L.) Gaudich. ex Wedd. - PUB & Urticaceae & 2 & 0.0241 & 8 \\
\hline Trema micrantha (L.) Blume - SWD & Cannabaceae & 2 & 0.0212 & 8 \\
\hline Myrciaria floribunda (West ex Willd.) O.Berg - ATL & Myrtaceae & 2 & 0.0166 & 8 \\
\hline Zanthoxylum petiolare A. St.-Hil. \& Tul. - PUB & Rutaceae & 2 & 0.0124 & 8 \\
\hline Eugenia ramboi D. Legrand - PUB & Myrtaceae & 2 & 0.0070 & 8 \\
\hline Citronella paniculata (Mart.) R.A.Howard - SWD & Cardiopteridaceae & 2 & 0.0561 & 4 \\
\hline Phytolacca dioica L. - SWD & Phylolaccaceae & 1 & 0.2166 & 4 \\
\hline Lonchocarpus muehlbergianus Hassl. - PUB & Fabaceae & 1 & 0.1767 & 4 \\
\hline Erythroxylum deciduum A. St.-Hil. - PUB & Erythroxylaceae & 1 & 0.1053 & 4 \\
\hline Enterolobium contortisiliquum (Vell.) Morong - PUB & Fabaceae & 1 & 0.0998 & 4 \\
\hline Solanum mauritianum Scop. - SWD & Solanaceae & 1 & 0.0484 & 4 \\
\hline Ocotea puberula (Rich.) Ness - SWD & Lauraceae & 1 & 0.0436 & 4 \\
\hline Ceiba speciosa (A.St.-Hill.) Ravenna - PUB & Malvaceae & 1 & 0.0418 & 4 \\
\hline Myrcia sp. & Myrtaceae & 1 & 0.0241 & 4 \\
\hline Erythroxylum myrsinites Mart. - SWD & Erythroxylaceae & 1 & 0.0127 & 4 \\
\hline Inga vera Willd. - PUB & Fabaceae & 1 & 0.0109 & 4 \\
\hline Campomanesia guazumifolia (Cambess.) O.Berg - PUB & Myrtaceae & 1 & 0.0097 & 4 \\
\hline Xylosma pseudosalzmannii Sleumer - PUB & Salicaceae & 1 & 0.0095 & 4 \\
\hline Seguieria guaranitica Speg. - SWD & Phytolaccaceae & 1 & 0.0095 & 4 \\
\hline Myrsine loefgrenii (Mez) Imkhan - SWD & Primulaceae & 1 & 0.0072 & 4 \\
\hline Eugenia uniflora L. - SWD & Myrtaceae & 1 & 0.0037 & 4 \\
\hline Allophylus guaraniticus (A. St.-Hil.) Radlk. - PUB & Sapindaceae & 1 & 0.0032 & 4 \\
\hline Symplocos lanceolata DC. - PUB & Symplocaceae & 1 & 0.0029 & 4 \\
\hline Cordiera concolor (Cham.) Kuntze - PUB & Rubiaceae & 1 & 0.0018 & 4 \\
\hline Eugenia rostrifolia D. Legrand - PUB & Myrtaceae & 1 & 0.0018 & 4 \\
\hline
\end{tabular}

$\mathrm{AD}$ - absolute density; ADo - absolute dominance; AF - absolute frequency; SWD - species of wide distribution; PUB - Paraná and Uruguay River Basin migration corridor (primary distribution); ATL - Atlantic corridor (primary distribution).

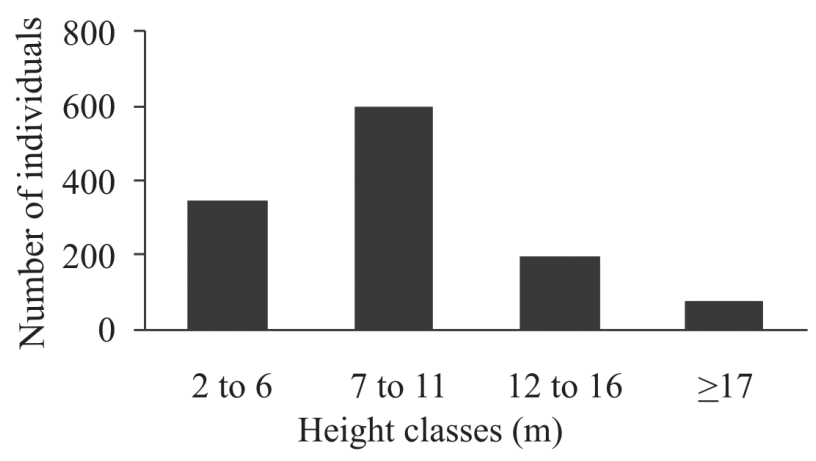

Figure 1. Distribution of individual trees in height classes in a subtropical seasonal forest in the upper Uruguay River Valley, southern Brazil. als from the species Cabralea canjerana and Cedrela fissilis, both reaching up to $25 \mathrm{~m}$. Among tree species characteristic of humid tropical climates, O. odorifera, Calyptranthes grandifolia, Calyptranthes lucida, Cordiera concolor and Coussarea contracta predominated.

Considering the relationships that species showed with the environmental and spatial variables, the eigenvalues of the four pCCAs were very low $(<0.15)$ for the first two axes (Tab. 2). Of the total variation in species, $\mathrm{pCCA}_{1}$ and $\mathrm{pCCA}_{2}$ explained $36.17 \%$ and $14.27 \%$, respectively, indicating that the most important relationship is purely environmental and therefore depends little on spatial aspects $\left(\mathrm{pCCA}_{3}\right)$. 
Table 2. Summary of partial canonical correspondence analysis of the abundance of 76 tree species sampled in a remnant of subtropical seasonal forest in the upper Uruguay River Valley, southern Brazil, showing interactions with environmental and spatial variables, as well as the results of the corresponding Monte Carlo permutation tests.

\begin{tabular}{|c|c|c|c|c|c|c|c|c|c|}
\hline \multirow{5}{*}{\multicolumn{2}{|c|}{ Parameters }} & \multicolumn{8}{|c|}{ pCCAs } \\
\hline & & \multicolumn{8}{|c|}{ Total inertia (sum of the eigenvalues): 1.219} \\
\hline & & \multirow{2}{*}{\multicolumn{2}{|c|}{$\frac{\mathrm{pCCA}_{1}}{\text { Environment }}$}} & \multirow{2}{*}{\multicolumn{2}{|c|}{$\frac{\mathrm{pCCA}_{2}}{\text { Space }}$}} & \multirow{2}{*}{\multicolumn{2}{|c|}{$\frac{\mathrm{pCCA}_{3}}{\text { Environment-Space }}$}} & \multicolumn{2}{|c|}{$\mathrm{pCCA}_{4}$} \\
\hline & & & & & & & & Space- & onment \\
\hline & & Axis 1 & Axis 2 & Axis 1 & Axis 2 & Axis 1 & Axis 2 & Axis 1 & Axis 2 \\
\hline Eigenvalues & & 0.126 & 0.105 & 0.115 & 0.077 & 0.115 & 0.089 & 0.076 & 0.063 \\
\hline Species vs. environment or space & & 0.864 & 0.870 & 0.816 & 0.842 & 0.928 & 0.914 & 0.847 & 0.922 \\
\hline \multicolumn{10}{|l|}{ Cumulative variation (\%) } \\
\hline Species data & & 10.3 & 19 & 9.5 & 15.8 & 11.6 & 20.6 & 9.8 & 17.9 \\
\hline Species vs. environment or space & & 28.5 & 52.4 & 50.1 & 83.6 & 29.7 & 52.7 & 43.5 & 80 \\
\hline Sum of canonical eigenvalues (trace) & & 0.441 & & 0.230 & & 0.386 & & 0.174 & \\
\hline \multicolumn{10}{|l|}{ Monte Carlo permutation tests } \\
\hline \multirow{2}{*}{ First canonical axis } & $\mathrm{F}$ & 2.071 & & 2.194 & & 1.966 & & 1.622 & \\
\hline & $p$ & 0.0595 & & 0.0037 & & 0.1051 & & 0.2232 & \\
\hline \multirow{2}{*}{ All canonical axes } & $\mathrm{F}$ & 1.703 & & 1.629 & & 1.598 & & 1.444 & \\
\hline & $p$ & 0.0002 & & 0.0015 & & 0.0025 & & 0.0352 & \\
\hline \multicolumn{10}{|l|}{ Internal correlations with axes (r) } \\
\hline Boron & & -0.24 & -0.20 & & & 0.07 & 0.65 & & \\
\hline Soil density & & 0.39 & 0.03 & & & 0.45 & 0.04 & & \\
\hline Sand & & -0.55 & 0.60 & & & 0.13 & 0.18 & & \\
\hline Organic material & & -0.21 & 0.07 & & & 0.10 & 0.42 & & \\
\hline Spatial variable $x$ & & & & -0.39 & 0.68 & & & 0.71 & -0.25 \\
\hline Spatial variable $y$ & & & & 0.40 & 0.72 & & & 0.35 & -0.83 \\
\hline Spatial variable $x y^{2}$ & & & & -0.17 & 0.75 & & & 0.76 & -0.34 \\
\hline
\end{tabular}

pCCA - partial canonical correspondence analysis.

However, $\mathrm{pCCA}_{3}$ and $\mathrm{pCCA}_{4}$ together explained $4.51 \%$ of the variation, indicating that the spatial structure of the environment itself plays a role. Therefore, more than half of the total variation (55\%) was explained by the environmental aspects, by the spatial aspects, or by the interaction between the two. However, $45.06 \%$ of species variation is stochastic or not explainable by the variables evaluated (Fig. 2). The Pearson's correlation coefficient ( $\mathrm{r}$ ) for species in relation to environmental variables and spatial variables showed higher values for the environmental variables in the first two axes, ranging from 0.86 to 0.87 , while those for the spatial variables ranged from 0.81 to 0.84 (Tab. 2). For all four pCCAs, Monte Carlo permutation tests indicated highly significant differences between the correlations found and those generated by chance, both for the first canonical axis and for the set of all canonical axes (Tab. 2).

Among the environmental variables, sand showed stronger correlations with $\mathrm{pCCA}_{1}$. Boron correlated weakly with the first axis of $\mathrm{pCCA}_{1}$ but was retained because of its strong correlation with the second axis of $\mathrm{pCCA}_{3}$. Soil density showed a weak correlation with the first axis of

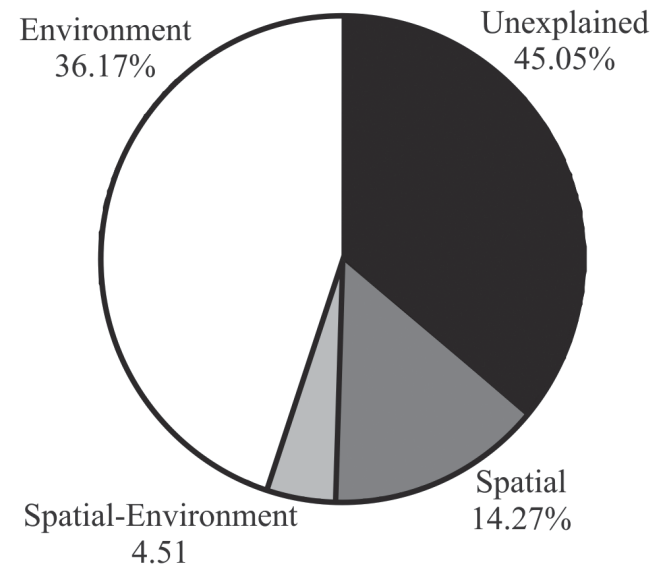

Figure 2. Proportional distribution of the factors explaining the variation in the matrix of species with a density of ${ }^{3} 5$ individuals in a stretch of subtropical seasonal forest in the upper Uruguay River Valley, southern Brazil.

pCCA but correlated more strongly with in the first axis of $\mathrm{pCCA}_{3}$. Organic matter was correlated with the second axis

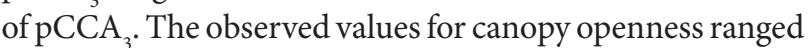
from $2.5 \%$ to $18 \%$ (mean, $8.5 \%$ ) and showed no influence on the distribution of species along the toposequence. 
The spatial variables, $x, y$ and $x y^{2}$ produced strong correlations $(r=0.68-0.83)$. The variable $x$ correlated strongly with the first axis of $\mathrm{pCCA}_{4}$. The variable $y$, which corresponds to the change in relief conformity (sloping) from the bottom to the top of the toposequence, presented significant correlations in the second axis of $\mathrm{pCCA}_{2}$, increasing to approximately 0.83 in the second axis of $\mathrm{pCCA}_{4}$. The spatial variable $x y^{2}$ showed correlations between approximately 0.75 and approximately 0.76 , in the second axis of $\mathrm{pCCA}_{2}$ and the first axis of $\mathrm{pCCA}_{4}$, respectively.

For the graphical representation of the analysis, we chose $\mathrm{pCCA}_{3}$ to explore only the effects of environmental variables (Fig. 3). The ordination separated the plots according to environmental variables, and soil density was negatively correlated with sand, boron and organic matter (Fig. 4).

The species ordination by pCCA (Fig. 4 and 5) suggested that the distribution of species such as Sloanea monosperma, Eugenia schuechiana, Cordia trichotoma and Casearia decandra was related to soils that had higher proportions of sand (those in the plots located at the base of the toposequence). At the other extreme of this gradient we observed species such as Apuleia leiocarpa, Parapiptadenia rigida, Nectandra lanceolata and Cupania vernalis. In intermediate conditions or conditions indifferent to environmental variables are species such as Gymnanthes concolor, Chrysophylum marginatum, Ocotea diospyrifolia and Trichilia claussenii.

As for the geographical distribution of species, we found that the vast majority of them occur along the migration corridor formed by the basins of the Paraná and Uruguay rivers, followed by species of wide distribution and finally by a small group of species characteristic of coastal areas (Atlantic corridor). Prominent in the latter group are $\mathrm{Ca}$ lyptranthes lucida, Calyptranthes grandifolia, Myrciaria floribunda, Ocotea odorifera and Zanthoxylum caribaeum (Tab. 1).

\section{Discussion}

\section{Composition and structure of the tree component}

The great species richness of Myrtaceae and Fabaceae has been considered a common pattern in forests in Brazil (Gandolfi et al. 1995; Ivanauskas et al. 1999; Durigan et al. 2000; Budke et al. 2004; Oliveira-Filho et al. 2006). Myrtaceae is considered a family with high richness in all forests in southern Brazil (Jurinitz \& Jarenkow 2003; Budke et al. 2004; Giehl \& Jarenkow 2008). For the family Fabaceae, in the seasonal forest along the upper Uruguay River, the richness and abundance of individuals are attributed mainly to the geographical location, which coincides with the entrance corridor of seasonal (tropical dry) species in Rio Grande do Sul, as opposed to the Atlantic corridor species, which occur in the rain forest (tropical humid) region to the east (Rambo 1961; Jarenkow \& Waechter 2001). This intermediate position on the gradient of east-west continentality

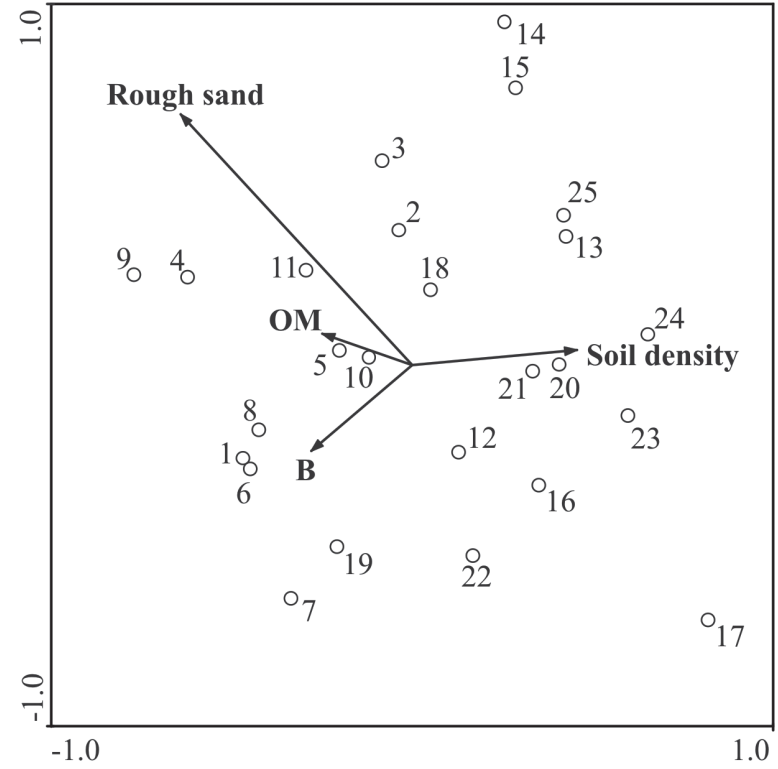

Figure 3. Ordination diagram of plots (species abundance) and environmental variables with significant association, representing the first two axes generated by partial canonical correspondence analysis, for the arboreal component in a subtropical seasonal forest in the upper Uruguay River Valley, southern Brazil. $\mathrm{OM}=$ organic matter, $\mathrm{B}=$ boron.

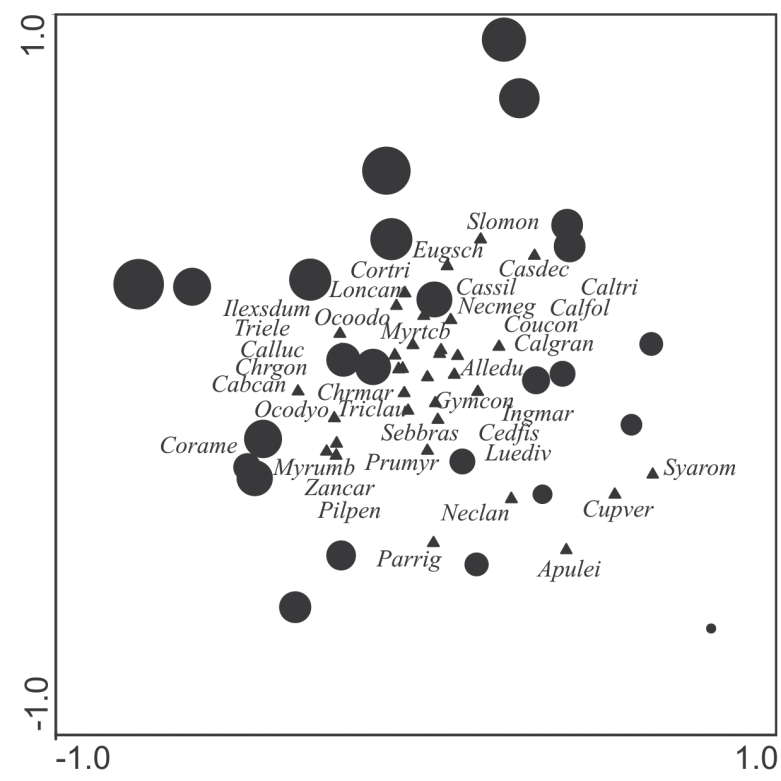

Figure 4. Ordination diagram of plots (species abundance) and the environmental variable "sand", representing the first two axes generated by partial canonical correspondence analysis for the arboreal component in a subtropical seasonal forest in the upper Uruguay River Valley, southern Brazil.

*The size of each circle represents the proportion of sand in each plot.

in South America (Oliveira-Filho et al. 2006), with some climatic and geographic variables that resemble those of more humid forests, allowed the occurrence of species from tropical moist environments, such as Ocotea odorifera, Calyptranthes grandifolia, Cordiera concolor, Myrciaria floribunda and Zanthoxylum caribaeum between subtropical 


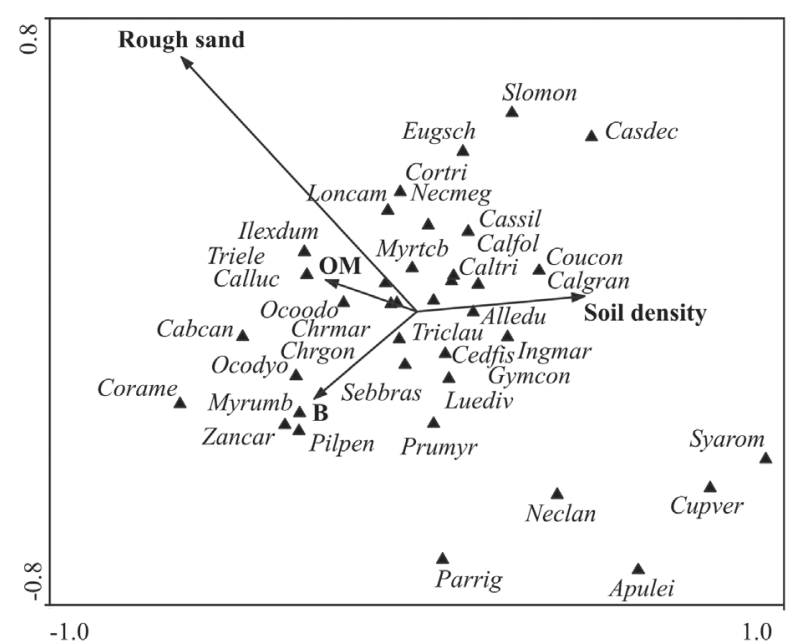

Figure 5. Ordination diagram for species $^{\star}$ with abundance -5 individuals and environmental variables with significant association, representing the first two axes generated by partial canonical correspondence analysis for the arboreal component in a subtropical seasonal forest in the upper Uruguay River Valley, southern Brazil.

B - boron, OM - organic matter.

* Species names have been abbreviated as shown in Table 1.

seasonal forests in the region of the upper Uruguay River. Likewise, the present study was the first recorded occurrence of Calyptranthes lucida in a non-coastal region of southern Brazil, indicating the possibility of dispersal of species from humid tropical areas over a larger geographical area, with subsequent retraction and current occurrence restricted to areas of lower elevation, along the upper Uruguay River. As a result, the forest remnants in areas that border the confluence of the Pelotas and Paraná rivers form an extremely important corridor for structural and phytogeographic studies, because they are home to a great diversity of species from other areas.

The species with the highest density in our study are also extremely abundant in other studies conducted in southern Brazil (Jarenkow \& Waechter 2001; Budke et al. 2004; Lindenmaier \& Budke 2006; Sühs \& Budke 2011). However, one aspect that stands out is the clear presence of individuals emerging from a dense canopy of moderate height. This pattern was also observed by Jarenkow \& Waechter (2001) for the central region of Rio Grande do Sul, where the deciduous element participates with a relatively low density and particularly with individuals reaching a large size. Nevertheless, species from the Atlantic corridor eventually generate a dense canopy and understory, especially with small trees.

\section{Relationships between species and spatial-environmental variables}

The eigenvalues of the first two ordination axes were low due to the high similarity between plots, which generated a short gradient with little species replacement. Much of the species distribution was found to be environmentally structured and less associated with the spatial variables, while the spatial variable $y$, corresponding to the pitch axis of the area in the north-south direction, was significant. A small portion of the fraction of the variation existing in the data itself is derived from the spatial autocorrelation between the distribution of the species and spatially structured variables, suggesting that the purely spatial effects play a minor role than do the environmental effects in explaining the variation in the species matrix. Notably, spatially explicit phenomena must be considered in terms of scale and experimental design, so as not to overestimate the influence of horizontal space in a community. Similarly, the proportion of the variation in the species matrix that could not be explained by the available environmental variables does not affect the significance of the species-environment relationships (Brack \& Smilauer 1998), and such "noise" is common in vegetation data, due in part to the fact that not all favorable sites are occupied by their respective species (Titeux et al. 2004).

The species distribution in the present study area was strongly correlated with soil texture. As expected, the plots located in the lower toposequence showed a higher proportion of sand, which allows inferences to be made regarding drainage, indicating that these area have high permeability and low water retention capacity. Through soil density, it is possible to evaluate the mass of material contained in a known volume; density allows us to evaluate the porosity and other textural characteristics of each sample. The fact that this variable was important in the distribution of some important species reveals a direct relationship with sand content, as sandy soils exhibit lower porosity than do clayey soils (Azevedo \& Dalmolin 2006).

The results we obtained for canopy discontinuity are considered intermediate in relation to the $9.0-26.0 \%$ reported for other semideciduous forests or even the $0.2-6.0 \%$ reported for evergreen forests (Martins \& Rodrigues 2002; Montgomery \& Chazdon 2002; van den Berg \& Santos 2003; Meira Neto et al. 2005). Although canopy discontinuity showed no correlation with individuals already established, it must certainly contribute to the distribution of regenerating individuals, as must other factors, such as the availability of water and nutrients. However, in the present study, canopy discontinuity was observed at a specific time of year (in the spring) and should also be measured during different seasons. If the discontinuity values are very low during other seasons, the remnants in question would not be classified as deciduous, as in other studies (Veloso et al. 1991), but would instead be classified as being in an intermediate position between seasonal broadleaf forests and evergreen forests.

The occurrence of species from tropical moist environments associated with the coastal rainforests of Brazil, indicates a likely retraction in the current geographical distribution of these species, making the upper Uruguay River an area of maintenance of forest species with disjunct 
distribution. The results also revealed that the distribution of many species is environmentally structured, reflecting the topographical conditions of the land, particularly those related to soil drainage, with less involvement of spatial variables in the explanation of the species distribution (low spatial autocorrelation). Although variation in species abundance occurs along the toposequence, the absence of catastrophic disturbances or even limiting factors or stress generated low species substitution throughout this topographical gradient.

\section{Acknowledgements}

The authors would like to thank Dr. Elisabete Maria Zanin, for her critical reading of the initial draft of the manuscript; the City of Marcelino Ramos, for providing access to the facilities within the protected area, as well as for granting permission to collect and work in the Parque Natural Municipal Mata do Rio Uruguai Teixeira Soares; the Laboratório de Sistemática e Ecologia Vegetal (ECOSSIS, Plant Systematics and Ecology Laboratory) of the Universidade Regional Integrada do Alto Uruguai e das Missões - URI, Campus de Erechim, for providing logistical support; and the anonymous reviewers, for their helpful suggestions and recommendations. This study received financial support from the URI Graduate Program in Ecology and from the Brazilian Conselho Nacional de Desenvolvimento Científico e Tecnológico (CNPq, National Council for Scientific and Technological Development; Grant no. 483775/2007).

\section{References}

APG III 2009. An update of the Angiosperm Phylogeny Group classification for the orders and families of flowering plants: APG II. Botanical Journal of the Linnean Society 161: 105-121.

Azevedo, A.C.de \& Dalmolin, R.S.D. 2006. Solos e ambiente: uma introdução. Santa Maria, Pallotti.

Behling, H. \& Pillar, VD.P. 2005. Late Quaternary vegetation, biodiversity and fire dynamics on the southern Brazilian highland and their implication for conservation and management of modern Araucaria forest and grassland ecosystems. Philosophical Transactions of The Royal Society B 362: 243-251.

Bell, G.; Lechowicz, M.J.; Appenzeller, A.; Chandler, M.; DeBlois, E.; Jackson, L.; Mackenzie, B.; Preziosi, R.; Schallenberg, M. \& Tinker, N. 1993. The spatial structure of the physical environment. Oecologia 96: $114-121$.

Bernardi, S. \& Budke, J.C. 2010. Estrutura da sinúsia epifítica e efeito de borda em uma área de transição entre Floresta Estacional Semidecídua e Floresta Ombrófila Mista. Revista Floresta 40: 81-92.

Borcard, D.; Legendre, P. \& Drapeau, P. 1992. Partialling out the spatial component of ecological variation. Ecology 73: 1042-1055.

Budke, J.C.; Giehl, E.L.H; Athayde, E.A.; Eisenger, S.M. \& Záchia, R.A. 2004. Florística e fitossociologia do componente arbóreo de uma floresta ribeirinha, arroio Passo das Tropas, Santa Maria, RS, Brasil. Acta Botanica Brasilica 18: 581-589.

Budke, J.C.; Jarenkow, J.A. \& Oliveira-Filho, A.T. 2010. Intermediary disturbance increases tree diversity in riverine Forest of southern Brazil. Biodiversity and Conservation 19: 2371-2387.

Clark, D.B.; Clark, D.A.; Rich, P.M.; Weiss, S. \& Oberbauer, S.F. 1996. Landscape-scale evaluation of understory light and canopy structure: methods and application in a neotropical lowland rain forest. Canadian Journal of Forest Research 26: 747-757.

Durigan, G.; Franco, G.A.D.C.; Saito, M. \& Baitello, J.B. 2000. Estrutura e diversidade do componente arbóreo da floresta na Estação Ecológica dos Caetetus, Gália, SP. Revista Brasileira de Botânica 23: 371-383.

Fetter, R. \& Henke-Oliveira, C. 2010. Mapeamento e diagnóstico ambiental do Parque Municipal Mata do Rio Uruguai Teixeira Soares. Pp. 153178. In: Santos, J.E.; Moschini, L.E. \& Zanin, E.M. (Orgs.). Faces da Polissemia da Paisagem. Vol. 3. São Carlos, RiMa.

Frazer, G.W.; Canham, C.D. \& Lertzman, K.P. 1999. Gap light analyzer (GLA): Imaging software to extract canopy structure and gap light transmission indices from true color fisheye photographs. Burnaby, Simon Fraser University \& New York, The Institute of Ecosystem Studies.

Giehl, E.L.H. \& Jarenkow, J.A. 2008. Gradiente estrutural no componente arbóreo e relação com inundações em uma floresta ribeirinha, rio Uruguai, sul do Brasil. Acta Botanica Brasilica 22: 741-753.

Huston, M.A. 1994. Biological diversity: the coexistence of species on changing landscapes. Cambridge, Cambridge University Press.

Ivanauskas, N.M.; Rodrigues, R.R. \& Nave, A.G. 1999. Fitossociologia de um trecho de Floresta Estacional Semidecídua em Itatinga, SP, Brasil. Scientia Florestalis 56: 83-99.

Jarenkow, J.A. \& Waechter, J.L. 2001. Composição, estrutura e relações florísticas do componente arbóreo de uma floresta estacional do Rio Grande do Sul, Brasil. Revista Brasileira de Botânica 24: 263-272.

Jarenkow, J.A. \& Budke, J.C. 2009. Padrões florísticos e análise estrutural de remanescentes florestais com Araucária angustifólia no Brasil. Pp. 113-126. In: Fonseca, C.S.D., Souza, A.F., Zanchet, A.M.L.; Dutra, T., Backes, A. \& Ganade, G.M.S. (Orgs.). Floresta com araucária: ecologia, conservação e desenvolvimento sustentável. Ribeirão Preto, Holos.

Jurinitz, C.F. \& Jarenkow, J.A. 2003. Estrutura do componente arbóreo de uma floresta estacional na Serra do Sudeste, Rio Grande do Sul, Brasil. Revista Brasileira de Botânica 26: 475-487.

Lindenmaier, D.S. \& Budke, J.C. 2006. Florística, diversidade e distribuição especial das espécies arbóreas em uma floresta estacional na bacia do Rio Jacuí, sul do Brasil. Pesquisas Botânica 57: 193-216.

Loregian, A.C.; Silva, B.B.; Zanin, E.M.; Decian, V.S.; Henke-Oliveira, C. \& Budke, J.C. 2012. Padrões espaciais e ecológicos refletem a estrutura em mosaicos de uma floresta subtropical. Acta Botanica Brasilica 26: 593-606.

Martins, S.V. \& Rodrigues, R.R. 2002. Gap-phase regeneration in a semideciduous mesophytic forest, south-eastern Brazil. Plant Ecology 163: 51-62.

Meira Neto, J.A.A.; Martins, F.R. \& Souza, A.L. 2005. Influência da cobertura e do solo na composição florística do sub-bosque em uma floresta estacional semidecidual em Viçosa, MG, Brasil. Acta Botanica Brasilica 19: 473-486.

Montgomery, R.A. \& Chazdon, R. 2002. Light gradient partitioning by tropical tree seedlings in the absence of canopy gaps. Oecologia 131:165-174.

Mueller-Dombois, D. \& Ellenberg, H. 1974. Aims and methods of vegetation ecology. New York, Willey.

Neary, D.G.; Ice, G.G. \& Jackson, C.R. Linkages between forest soils and water quality and quantity. 2009. Forest Ecology and Management 258: 2269-2281.

Oliveira-Filho, A.T.; Jarenkow, J.A. \& Rodal, M.J.N. 2006. Floristic relationships of Seasonally Dry Forest of eastern South American based on tree species distribution patterns. Pp. 159-192. In: Pennington, R.T.; Lewis, G.P.; Ratter, J.A. (Orgs.). Neotropical savannas and dry forests: plant diversity, biogeography and conservation. Boca Raton, CRC Press.

Oliveira-Filho, A.T. 2009. Classificação das fitofisionomias da América do Sul extra- Andina: proposta de um novo sistema prático e flexível ou injeção a mais de caos? Rodriguésia 60: 237-258.

Rambo, B. 1961. Migration routes of the south Brazilian rain forest. Pesquisas Botânica 12: 1-54.

Santos, R.D.; Lemos, R.C.; Santos, H.G.; Ker, J.C. \& Anjos, L.H.C. 2005. Manual de descrição e coleta de solo no campo. Viçosa, Sociedade Brasileira de Ciência do Solo. 
Shepherd, G.J. 2006. Fitopac 2: manual do usuário. Campinas, Unicamp. Sobral, M.; Jarenkow, J.A.; Brack, P.; Irgang, B.; Larocca, J. \& Rodrigues, R.S. 2006. Flora arbórea e arborescente do Rio Grande do Sul, Brasil. São Carlos, RiMA/Novo Ambiente.

Sühs, R.B. \& Budke, J.C. 2011. Spatial distribution, association patterns and richness of tree species in a seasonal forest from the Serra Geral formation, southern Brazil. Acta Botanica Brasilica 25: 602-614.

ter Braak, C.J.F. \& Smilauer, P. 1998. CANOCO 4.0 - Reference manual and user's guide to Canoco for Windows: software for canonical community ordination. Microcomputer Power.
Titeux, N.; Dufrene, M.; Jacob, J.; Paquay, M. \& Defourny, P. 2004. Multivariate analysis of a fine-scale breeding bird atlas using a geographical information system and partial canonical correspondence analysis: environmental and spatial effects. Journal of Biogeography 31: 1841-1856.

van den Berg, E. \& Santos, F.A.M. 2003. Aspectos da variação ambiental em uma floresta de galeria em Itutinga, MG, Brasil. Ciência Florestal 13: 82-98.

Veloso, H.P.; Rangel Filho, A.L.R. \& Lima, J.C.A. 1991. Classificação da vegetação brasileira, adaptada a um sistema universal. Brasília, IBGE. 